\title{
Heavy Metals in the Muscle and Hepatopancreas of Red Swamp Crayfish (Procambarus clarkii) in Campania (Italy)
}

\author{
Andrea Ariano ${ }^{1}$, Marcello Scivicco ${ }^{1}$, Massimiliano D'Ambola ${ }^{1}$, Salvatore Velotto ${ }^{2}$, Rebecca Andreini ${ }^{3, *}$, \\ Simone Bertini ${ }^{4}{ }^{\infty}$, Annalisa Zaccaroni ${ }^{3}$ and Lorella Severino ${ }^{1}$ \\ 1 Department of Veterinary Medicine and Animal Production, Division of Toxicology, \\ University of Naples Federico II, Via Delpino 1, 80137 Naples, Italy; andrea.ariano@unina.it (A.A.); \\ marcello.scivicco@unina.it (M.S.); m.dambola@hotmail.it (M.D.); lorella.severino@unina.it (L.S.) \\ 2 Department of Promotion of Human Sciences and the Quality of Life, University San Raffaele, Via di Val \\ Cannuta 247, 00166 Roma, Italy; salvatore.velotto@uniroma5.it \\ 3 Department of Veterinary Medical Sciences, University of Bologna, Viale Vespucci 2, 47042 Cesenatico, Italy; \\ annalisa.zaccaroni@unibo.it \\ 4 Department of Veterinary Science, University of Parma, 43126 Parma, Italy; simone.bertini@unipr.it \\ * Correspondence: rebeccaandreini@libero.it
}

check for updates

Citation: Ariano, A.; Scivicco, M.; D'Ambola, M.; Velotto, S.; Andreini,

R.; Bertini, S.; Zaccaroni, A.; Severino,

L. Heavy Metals in the Muscle and

Hepatopancreas of Red Swamp

Crayfish (Procambarus clarkii) in Campania (Italy). Animals 2021, 11, 1933. https://doi.org/10.3390/ ani11071933

Academic Editor: Vittorio

Maria Moretti

Received: 9 June 2021

Accepted: 23 June 2021

Published: 29 June 2021

Publisher's Note: MDPI stays neutral with regard to jurisdictional claims in published maps and institutional affiliations.

Copyright: (c) 2021 by the authors. Licensee MDPI, Basel, Switzerland. This article is an open access article distributed under the terms and conditions of the Creative Commons Attribution (CC BY) license (https:/ / creativecommons.org/licenses/by/ $4.0 /)$.
Simple Summary: Heavy metals can represent a serious threat to marine and freshwater fauna through exposure, bioaccumulation and biomagnification processes. The aim of this study was to evaluate the presence of non-essential and essential elements in freshwater crayfish (Procambarus clarkii) edible tissues to establish the healthiness of this product and to evaluate the pollution status of the sampling sites from Campania region (Italy). The results suggest that crayfish were safe for human consumption and indicated mild contamination of heavy metals of the sampling areas.

Abstract: The aim of this study was to carry out a quali-quantitative analysis of the presence of non-essential and essential trace elements in freshwater crayfish (Procambarus clarkii) edible tissues to establish the healthiness of this product and to evaluate the pollution status of the sampling sites included in the present study. P. clarkii is one of the most common species of freshwater crustaceans in Italy, regularly consumed by local people. Moreover, the crayfish, due to its trophic position and diet, can be considered as an excellent bioindicator of the health status of the ecosystem. We collected sixty crayfish samples from two different sites in Campania (Italy): Villa Literno and Sessa Aurunca. Concentrations of trace elements were determined by Inductively Coupled Plasma Optical Emission Spectroscopy (ICP-OES). Our data showed low concentrations of $\mathrm{Cd}, \mathrm{Hg}$ and $\mathrm{Pb}$, with values below the European Commission MRL (Commission Regulation (EC) 1881/2006). We suggest that data obtained from this study showed that crayfish collected from Villa Literno and Sessa Aurunca were safe for human consumption. Furthermore, the results of this research indicated mild contamination of heavy metals of the sampling sites, indicating a good health status of the area's aquatic ecosystem.

Keywords: heavy metals; crustaceans; bioindicator; anthropogenic pollutant

\section{Introduction}

Trace elements are classified by the scientific community as non-essential and essential. Non-essential trace elements have no biological role in animal organisms and represent a serious threat to aquatic fauna. Heavy metals and metalloids such as arsenic, lead, cadmium and mercury originate from natural sources and human activities (mining, metal production, combustion of fossil fuels, sewage sludge and waste incineration) [1,2] and are spread worldwide in fresh and salty waters, becoming one of the major causes of persistent aquatic pollution. Trace elements enter the food chain through bioaccumulation and biomagnification processes, contributing to compromising the balance of the food chain for a long time [3]. Adverse effects linked to acute or chronic exposure to metals 
include damages to the immune system, helping the onset of infectious diseases, and interference with the endocrine system, leading to reproductive alterations. Among the freshwater fauna, crustaceans are one of the most sensitive macroinvertebrate species to suffer negative effects of exposure to metals due to their diet, way of feeding with direct contact with sediments, and life span [4-6], and they easily accumulate trace elements in the hepatopancreas, the target organ for metals investigation [7-10]. Since crustaceans are extremely sensitive to metal effects, are widely spread in aquatic ecosystems and are regularly consumed by humans, they represent an optimal bioindicator to gain information about the health status of the ecosystem and to determine safety and quality of food intended for human consumption. In our study, we focused on the red swamp crayfish Procambarus clarkii (Girard, 1852), which is common in the sampling areas we included in the study and usually consumed by local people. Moreover, P. clarkii is considered by the scientific community as an optimal bioindicator for trace elements contamination [11,12]. Indeed, the red swamp crayfish has been used as an indicator species to monitor the environmental quality and the contamination of biological habitats in previous studies [7,13-17]. Nowadays, the red swamp crayfish is listed in Italy as an invasive species. It originates from the United States and Mexico and arrived in Europe during the last century, for aquaculture purposes [18]. Unfortunately, most of the Italian farmers failed to take adequate precautions in their cultivation methods to prevent the crayfish escape from farm enclosers. Soon after, the red swamp crayfish established wild stable populations in many lakes and ponds across Italy and rapidly became the dominant freshwater crayfish $[19,20]$. Regarding the sampling areas, we focused our attention on geographic areas of the Campania region (Italy) which are well known to be characterized by high pollution of soil, fresh, salty water and groundwater. These sites represent ex-industrial areas and are located nearby illegal waste dumps [21]. Specifically, since the 1980s Naples and Caserta have been exploited as illegal landfills of toxic waste. Such operations and the accumulation of toxic products have had a serious impact on the ecosystem of the coast and the hinterland, influencing health and future development of the local fauna and human population [22]. In the present study, we performed a quali-quantitative analysis of trace elements in samples of hepatopancreas and abdominal muscle of $P$. clarkii collected in two different Italian sampling sites, selected for their potential high level of metal contamination. We sought to identify sources of pollution in the study area, to assess public health risk linked to consumption of crayfishes and to improve the current knowledge about the use of $P$. clarkii as a bioindicator of heavy metal pollution in freshwater ecosystems.

\section{Materials and Methods}

\subsection{Sampling}

Sixty samples of red swamp crayfish were collected during summer 2017. Crayfishes were captured using baited traps placed at Villa Literno (ViL), near the Volturno River, and at Sessa Aurunca (SeA), near the Garigliano River (Figure 1) in the Campania region. No data is at present available concerning pollution of the two areas, apart from one study reporting trace elements concentration in the blood of dogs from Sessa Aurunca [23]. Specimens were then transferred alive in refrigerated boxes $\left(4-8{ }^{\circ} \mathrm{C}\right)$ to the laboratory. In our facility, crayfishes were weighed and sexed. Furthermore, we measured each carapace length using a caliper (Absolute Digimatic caliper, Mitutoyo, Japan) (Table 1), from the tip of the rostrum to the edge of the carapace. Crayfishes were euthanized by thermal shock $\left(-80^{\circ} \mathrm{C}\right.$ for $\left.30 \mathrm{~min}\right)$. Subsequently, the abdominal muscle and the hepatopancreas were removed under partially defrosting conditions and stored in Falcon tubes at $-20^{\circ} \mathrm{C}$ until further analyses. 


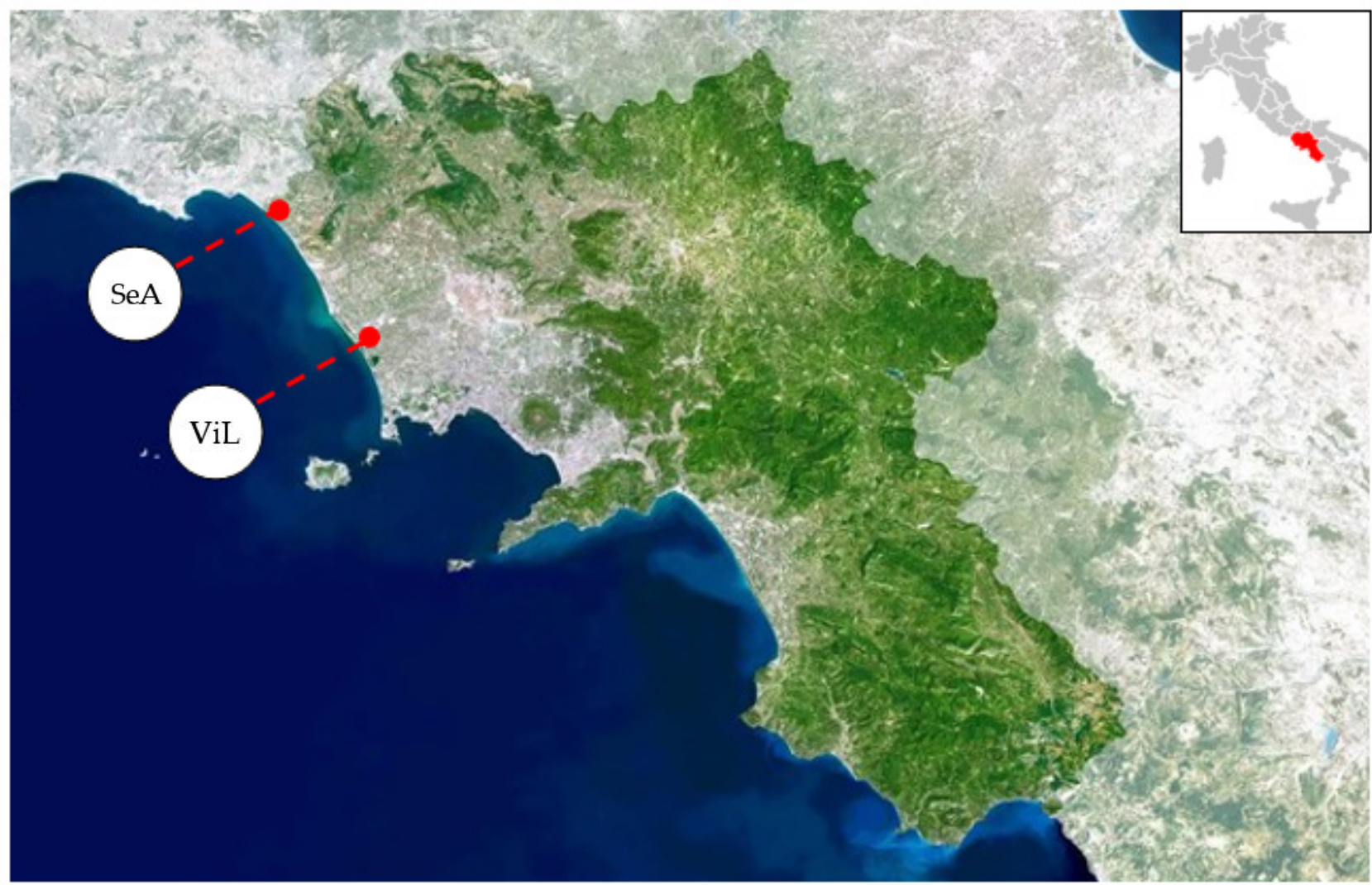

Figure 1. Map showing locations of the sampling sites: Villa Literno (ViL) and Sessa Aurunca (SeA).

Table 1. Number of individuals (n), weight $(\mathrm{g})$, size $(\mathrm{mm})$ and sex of Procambarus clarkii captured at Villa Literno and Sessa Aurunca.

\begin{tabular}{|c|c|c|c|c|}
\hline Sites & $n$ & Mean Weight $(g) \pm$ SD & Mean Total Lenght $(\mathrm{cm}) \pm \mathrm{SD}$ & Sex \\
\hline Villa Literno (ViL) & 30 & $28.19 \pm 4.43$ & $9.58 \pm 0.67$ & $\begin{array}{c}17 \text { o } \\
13 \sigma^{7}\end{array}$ \\
\hline Sessa Aurunca (SeA) & 30 & $27.81 \pm 3.51$ & $9.32 \pm 0.59$ & $\begin{array}{c}16 \text { ? } \\
140^{1}\end{array}$ \\
\hline
\end{tabular}

\subsection{Chemical and Instrumental Analysis}

Each sample was homogenized and $0.5 \pm 0.2 \mathrm{~g}$ of tissue was added to $5 \mathrm{~mL}$ of $65 \%$ $\mathrm{HNO}_{3}$ and $2.0 \mathrm{~mL}$ of $30 \% \mathrm{H}_{2} \mathrm{O}_{2}$. Microwave-assisted digestion was performed with a specific mineralization program for $25 \mathrm{~min}$ at $190^{\circ} \mathrm{C}$. Samples were cooled at $32{ }^{\circ} \mathrm{C}$ and the digested mixture was transferred into a $50.0 \mathrm{~mL}$ flask and the final volume was obtained by adding Milli-Q water [24].

Trace elements detection and quantification were determined by ICP-OES technique using a Perkin Elmer Optima 2100 DV instrument coupled with a CETAC U5000AT. Subsequently, both metals quantification and quality assurance procedure were performed as described by Zaccaroni et al. [23]. LODs values (limit of detection values) as wet weight were: $0.024 \mu \mathrm{g} \mathrm{g}^{-1}$ for As; $0.0002 \mu \mathrm{g} \mathrm{g}^{-1}$ for $\mathrm{Cu} ; 0.006 \mu \mathrm{g} \mathrm{g}{ }^{-1}$ for $\mathrm{Zn} ; 0.001 \mu \mathrm{g} \mathrm{g}{ }^{-1}$ for $\mathrm{Cr}$; $0.0018 \mu \mathrm{g} \mathrm{g}^{-1}$ for $\mathrm{Cd} ; 0.011 \mu \mathrm{g} \mathrm{g}^{-1}$ for $\mathrm{Pb} ; 0.001 \mu \mathrm{g} \mathrm{g}^{-1}$ for $\mathrm{Hg}$. The performance of the method has been defined by interlaboratory studies organized by FAPAS (Food Analysis Performance Assessment Scheme, Sand Hutton, York, UK). 


\subsection{Statistical Analysis}

Results are reported in wet weight as mean \pm SEM (standard error) [25]. Statistical significance of the influence of sampling sites (ViL Vs. SeA) and statistical significance in concentrations of trace elements in target organs (muscle vs. hepatopancreas) were tested using factorial analysis of variance. Furthermore, we apply the ANOVA test to highlight differences between trace element accumulation in the hepatopancreas and the muscle and between the sampling areas. Multiple regression was used to discover statistical significance between trace element concentration and intrinsic variables (as total weight and gender of specimens). One-Sample Kolmogorov-Smirnov Test confirmed the normal distribution of our data. All our statistical analyses have been performed using MedCalc for Windows, version 18.11.3 (MedCalc Software, Ostend, Belgium). Significant value has been established at $p<0.05$.

\section{Results}

Mean concentrations of $\mathrm{As}, \mathrm{Cu}, \mathrm{Zn}$ and $\mathrm{Cr}$ in abdominal muscle (AbM) and hepatopancreas (Hep) of P. clarkii are summarized in Figure 2.
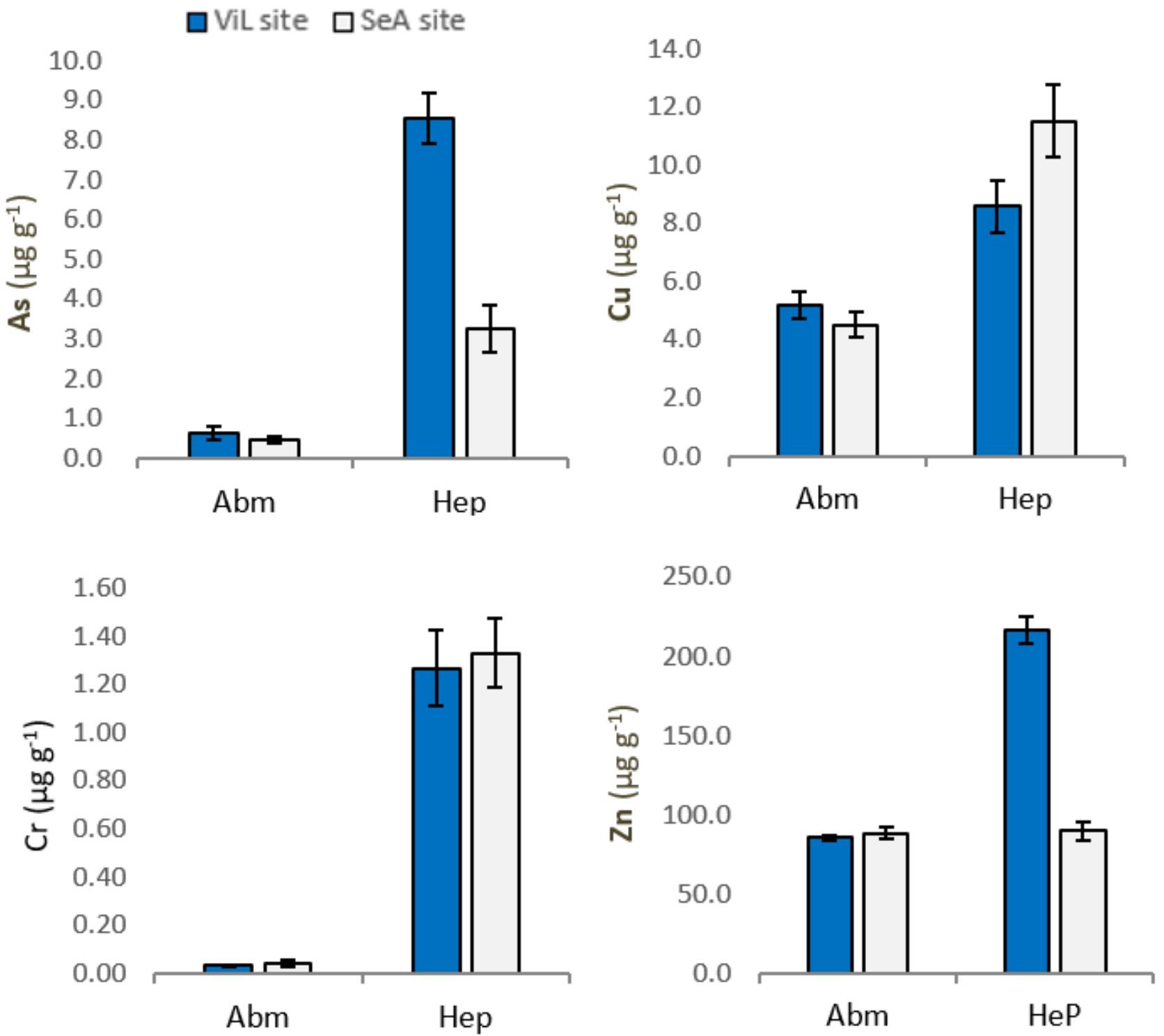

Figure 2. Concentrations of $\mathrm{As}, \mathrm{Cu}, \mathrm{Zn}$ and $\mathrm{Cr}$ in Procambarus clarkii abdominal muscle (AbM) and hepatopancreas (Hep) from Villa Literno (ViL) and Sessa Aurunca (SeA). Vertical bars represent average concentration ( $\mu \mathrm{g} \mathrm{g}^{-1}$ wet weigth) \pm SEM. 
Our results show a variability in the concentration of two trace elements in P. clarkii, depending on sampling sites. Specifically, the levels of As and Zn were significantly higher $(p<0.01)$ in P. clarkii tissue from ViL site. Significant differences in organ accumulation of As, $\mathrm{Cr}, \mathrm{Cu}$ and $\mathrm{Zn}$ have been highlighted. Indeed, trace elements concentration was significantly higher in hepatopancreas than in muscle (Table 2.). In Hep, Arsenic was found at a mean concentration of 8.534 and $3.248 \mu \mathrm{g} \mathrm{g}^{-1}$, while in AbM mean values were 0.627 and $0.456 \mu \mathrm{g} \mathrm{g}^{-1}$, in ViL site $(p<0.01)$ and SeA site $(p<0.01)$, respectively. Our data show, both in samples from SeA site and Vil site, significant differences $(p<0.01)$ between $\mathrm{Cu}$ concentration in Hep and AbM. In addition, significant differences $(p<0.01)$ were found for $\mathrm{Zn}$ between Hep and AbM at ViL site. Finally, higher concentrations of $\mathrm{Cr}$ were found in the crayfish Hep compared AbM at both sampling sites $(p<0.01)$.

Table 2. Mean concentration ( $\mu \mathrm{g} \mathrm{g}^{-1}$ wet weigth) \pm SEM of trace elements (As, Cu, $\mathrm{Zn}, \mathrm{Cr}, \mathrm{Cd}$, $\mathrm{Pb}$ and $\mathrm{Hg}$ ) in Procambarus clarki abdominal muscle (AbM) and hepatopancreas (Hep) from Villa Literno (ViL) and Sessa Aurunca (SeA).

\begin{tabular}{|c|c|c|c|c|}
\hline $\begin{array}{c}\text { Trace Elements } \\
\left(\mu g g^{-1} \text { Wet Weight) }\right.\end{array}$ & $\begin{array}{c}\text { AbM } \\
\text { ViL Site }\end{array}$ & $\begin{array}{c}\text { Hep } \\
\text { ViL Site }\end{array}$ & $\begin{array}{c}\text { AbM } \\
\text { SeA Site }\end{array}$ & $\begin{array}{c}\text { Hep } \\
\text { SeA Site }\end{array}$ \\
\hline As & $\begin{array}{l}0.627^{\mathrm{A}} \\
\pm 0.173\end{array}$ & $\begin{array}{l}8.534^{\mathrm{B}} \\
\pm 0.628\end{array}$ & $\begin{array}{l}0.456^{\mathrm{A}} \\
\pm 0.092\end{array}$ & $\begin{array}{l}3.248^{\mathrm{B}} \\
\pm 0.605\end{array}$ \\
\hline $\mathrm{Cu}$ & $\begin{array}{l}5.172^{\mathrm{a}} \\
\pm 0.450\end{array}$ & $\begin{array}{l}8.577^{b} \\
\pm 0.896\end{array}$ & $\begin{array}{l}4.518^{\mathrm{A}} \\
\pm 0.461\end{array}$ & $\begin{array}{l}11.512^{\mathrm{A}} \\
\pm 1.239\end{array}$ \\
\hline $\mathrm{Zn}$ & $\begin{array}{c}85.553 \mathrm{~A} \\
\pm 1.788\end{array}$ & $\begin{array}{l}216.643^{B} \\
\pm 8.225\end{array}$ & $\begin{array}{l}87.961 \\
\pm 3.753\end{array}$ & $\begin{array}{l}89.617 \\
\pm 6.091\end{array}$ \\
\hline $\mathrm{Cr}$ & $\begin{array}{l}0.031^{\mathrm{A}} \\
\pm 0.002\end{array}$ & $\begin{array}{l}1.265^{\mathrm{B}} \\
\pm 0.157\end{array}$ & $\begin{array}{l}0.042^{\mathrm{A}} \\
\pm 0.016\end{array}$ & $\begin{array}{l}1.328^{\mathrm{B}} \\
\pm 0.144\end{array}$ \\
\hline $\mathrm{Cd}$ & $<\mathrm{dl}$ & $\begin{array}{c}0.020 \\
\pm 0.002\end{array}$ & $<\mathrm{dl}$ & $\begin{array}{c}0.018 \\
\pm 0.002\end{array}$ \\
\hline $\mathrm{Pb}$ & $<\mathrm{dl}$ & $\begin{array}{c}0.015 \\
\pm 0.002\end{array}$ & $<\mathrm{dl}$ & $\begin{array}{c}0.012 \\
\pm 0.001\end{array}$ \\
\hline $\mathrm{Hg}$ & $<\mathrm{dl}$ & $<\mathrm{dl}$ & $<\mathrm{dl}$ & $<\mathrm{dl}$ \\
\hline
\end{tabular}

Probability levels for significant differences depending on organ type: AbM versus Hep: A, B: $p<0.01, \mathrm{a}, \mathrm{b}$ : $p<0.05$.

Results showed negligible levels of $\mathrm{Cd}$ and $\mathrm{Pb}$ in all samples of the crayfish $\mathrm{AbM}$. In the Hep, Cd was found at a mean concentration of 0.020 and $0.018 \mu \mathrm{g} \mathrm{g}^{-1} ; \mathrm{Pb}$ was found at a mean concentration of 0.015 and $0.012 \mu \mathrm{g} \mathrm{g}^{-1}$ in Villa Literno (ViL site) and Sessa Aurunca (SeA site), respectively. Mercury was found under the detection limit (dl) in all analyzed samples (Table 2).

The analyzed individuals varied in size and weight ranges, including males and females. The multiple regression analyses indicate that there were no correlations between weight, gender and concentration of all analyzed trace elements $(p>0.05)$.

\section{Discussion}

The absence of a relation between trace elements and gender agrees with other published studies on $P$. clarkii $[13,16,26]$. Moreover, we did not appreciate a significant link between trace element concentration in the analyzed tissues and the weight of specimens, suggesting that these parameters have a minor effect on metal accumulation in subjects inside the weight range considered in this study [24].

Arsenic concentrations found in the crayfish muscle are comparable to results obtained by Bellante et al. (0.537 $\mu \mathrm{g} \mathrm{g}^{-1}$ w.w. $)$. In the same study the concentration of As in hepatopancreas was lower than those found in the present study $\left(1.128 \mu \mathrm{g} \mathrm{g}^{-1}\right.$ w.w. $)$ [16]. Comparable levels of As in muscle were found by Gedik et al. in crayfish from Lousiana [14]. Devesa et al. [27] report arsenic concentration ranging from 9.2 to $12 \mu \mathrm{g} \mathrm{g}^{-1}$ in muscle 
and from 2.5 to $2.6 \mu \mathrm{g} \mathrm{g}^{-1}$ in hepatopancreas of crayfish from Southern Spain, higher than those found in the present study. On the contrary, Mistri et al. [28] and Tan et al. [29] report mean As concentration in both Hep and AbM lower than those detected in present study.

Regarding essential trace element concentrations, previous studies reported variable values of copper and zinc levels in the crayfish tissues. Among them, Bellante et al. [16] reported $\mathrm{Cu}$ levels in crayfish hepatopancreas and muscle ranging from 1.149 to $48.3 \mu \mathrm{g} \mathrm{g}^{-1}$ (mean value $12.3 \mu \mathrm{g} \mathrm{g}^{-1}$ ) and from 1.34 to $12.72 \mu \mathrm{g} \mathrm{g}^{-1}$ (mean value $5.19 \mu \mathrm{g} \mathrm{g}^{-1}$ ) w.w., respectively. These data agree with the results of the present study. Similarly, Kuklina et al. [30] and Mistri et al. [28] report comparable $\mathrm{Cu}$ concentrations in both tissues. Despite this, another study conducted in Lousiana established a range for $\mathrm{Cu}$ and $\mathrm{Zn}$ concentrations in the crayfish muscle ranging from 23.8 to $44.2 \mu \mathrm{g} \mathrm{g}^{-1}$ and from 41.3 to $55.8 \mu \mathrm{g} \mathrm{g}^{-1}$, respectively [31]. Moreover, a recent study conducted in Central Italy showed Cu levels that varied from 23 to $1031 \mu \mathrm{g} \mathrm{g}^{-1}$ in Hep and from 27 to $187 \mu \mathrm{g} \mathrm{g}^{-1}$ in AbM [15]. Cu levels in the hepatopancreas and muscle reported by those authors were higher than those detected in the present study, while Zn levels in Hep and AbM were lower than those found in ViL and SeA sites.

Regarding $\mathrm{Cr}$ concentrations, Bellante et al. [16] reported levels in crayfish hepatopancreas and muscle of $0.915 \mu \mathrm{g} \mathrm{g}^{-1}$ and $0.24 \mu \mathrm{g} \mathrm{g}^{-1}$ w.w., respectively. Mancinelli et al. [13], reported $\mathrm{Cr}$ in muscle tissue of P. clarkii $\left(0.20-0.29 \mu \mathrm{g} \mathrm{g}{ }^{-1}\right)$ at higher concentrations than those found in AbM in ViL and SeA. Kuklina et al. [30] and Tan et al. [29] report similar Cr concentrations in the Hep to those detected in present research, while levels detected in $\mathrm{AbM}$ are higher in Campania samples with respect to these two studies.

Detection of $\mathrm{Cd}$ and $\mathrm{Pb}$ has been widely explored in crayfish. The levels of $\mathrm{Cd}$ in $\mathrm{AbM}$ of ViL site and SeA site, respectively, are generally comparable with those found in the muscle of P. clarkii from Preola Lake $\left(<\mathrm{dl}-0.01 \mu \mathrm{g} \mathrm{g}{ }^{-1}\right.$ d.w. $)$ and Gorgo Medio Lake $\left(<\mathrm{dl}-0.03 \mu \mathrm{g} \mathrm{g}^{-1}\right.$ d.w.) in Sicily, Italy [16], and lower than those reported in crayfish muscle from Trasimeno Lake $\left(0.05 \mu \mathrm{g} \mathrm{g}^{-1}\right.$ and $\left.2.2 \mu \mathrm{g} \mathrm{g}^{-1}\right)$ and Bolsena Lake $\left(0.03 \mu \mathrm{g} \mathrm{g}^{-1}\right)$ in Central Italy $[13,15]$. The levels of $\mathrm{Pb}$ accumulated in $\mathrm{AbM}$ and Hep determined in our research are also lower than concentrations measured in other areas [15-17].

Cadmium concentrations found in Hep of ViL site and SeA site are comparable to those measured in hepatopancreas of P. clarkii from Preola Lake and Gorgo Medio Lake in Sicily, Italy [16], but lower than the ones reported by other authors [7]. In 2016, Goretti et al. [15], detected $\mathrm{Cd}$ (mean value $8.2 \mu \mathrm{g} \mathrm{g}^{-1}$ unpolluted area; $28.2 \mu \mathrm{g} \mathrm{g}^{-1}$ polluted area) and $\mathrm{Pb}$ (mean value $8.5 \mu \mathrm{g} \mathrm{g}^{-1}$ unpolluted area; $3.2 \mu \mathrm{g} \mathrm{g}^{-1}$ polluted area) in the hepatopancres of P. clarkii from Trasimeno Lake (Cental Italy) at higher levels than those found in ViL and SeA sites. Same results were reported for both $\mathrm{Cd}$ and Pb by Tan et al. [29], Mistri et al. [28] and Kuklina et al. [30].

The general evidence was that crayfishes from ViL and SeA accumulated higher levels of metals (As, $\mathrm{Cu}, \mathrm{Zn}$ and $\mathrm{Cr}$ ) in Hep than in $\mathrm{AbM}$, in accordance with those reported in literature [7,14-16]. Almost all studies on the distribution of trace elements in crayfish tissues showed that the hepatopancreas is the target organ of storage and detoxification of heavy metals [7-10]. However, in the present study, no statistical differences were reported for $\mathrm{Cd}$ and $\mathrm{Pb}$ concentrations in $\mathrm{AbM}$ and Hep of P. clarkii, probably due to the negligible concentrations of these non-essential trace elements in the aquatic environment of both sampling sites.

\section{Concern for Public Health}

Even though no European or Italian regulation for $\mathrm{As}, \mathrm{Cu}, \mathrm{Zn}$ and $\mathrm{Cr}$ concentration in crustaceans and food products exists (because they are considered as essential trace elements, necessary for specific physiological functions), some tolerable upper intake levels have been proposed by both American and EU governmental and research entities (National Institutes of Health, U.S., Department of Health and Human Services; German Federal Institute for Risk Assessment, BfR; Scientific Committee on Food, European Commission, SCF; EFSA). 
Copper is easily found in the environment and is essential for normal growth and metabolism [32]. Additionally, it is a component of the respiratory metalloprotein hemocyanin in crustaceans [33]. Therefore, relatively high copper amounts may be found in crayfish tissues, mainly in the hepatopancreas [7,34]. The role of $\mathrm{Cu}$ in crayfish metabolism and its great variability in data reported by other studies make comparison difficult, but the concentrations of $\mathrm{Cu}$ found in the present study are generally similar or higher than those reported in nine crayfishes captured both in polluted and unpolluted study areas [16]. Detected levels of copper are well above the recommended dietary allowances for toddlers and for adults (0.14-0.15 $\mu \mathrm{g} \mathrm{g}^{-1}$ respectively) set by NIH [35] and of $0.08 \mu \mathrm{g} \mathrm{g}^{-1}$ for adults defined by BfR, SCF and EFSA [36-38].

The concentrations of $\mathrm{Zn}$ were higher than concentrations found by other authors in polluted and unpolluted areas [16,31,39]. Our results are indicative of high Zn levels, especially in the ViL site. These levels exceed the tolerable upper intake level (UL) defined by the SCF of $0.41 \mu \mathrm{g} \mathrm{g}^{-1}$ for adults [40].

Anyway, it should be noted that crayfish consumption is not that common among the Italian population, and the quantity of flesh usually consumed is generally reduced, so for both $\mathrm{Cu}$ and $\mathrm{Zn}$ a reduced exposure, and consequent health risk, is expected.

Chromium levels detected in Hep and AbM are comparable or lower than those reported by other authors [13,16]. Furthermore, $\mathrm{Cr}$ concentrations in AbM are below the threshold concentration suggested by FDA [41] of $1.089 \mu \mathrm{g} \mathrm{g}^{-1}$ w.w. for human consumption. Anyway, it is important to remember that also an excess of these metals can potentially cause harmful effects in organisms $[10,42]$. No UL has been defined for Chromium, but the WHO suggested to not exceed a $250 \mu \mathrm{g} /$ day supplementation, equivalent to a daily dose of $4.16 \mu \mathrm{g} \mathrm{g}^{-1}$, if using a standard weight of $60 \mathrm{~kg}[43,44]$.

Although our results are suggestive of higher levels of As in Hep, especially in the ViL site, concentrations of As in $\mathrm{AbM}$ are comparable to those reported in the literature and considered concentration responsible for low risk for human consumption [14]. No UL has been set for As at present by any governmental institution, but a maximum concentration of $50 \mu \mathrm{g} \mathrm{L}^{-1}$ has been defined [35], well below the mean concentrations detected in present study. Anyway, it should be remembered that the substantial portion of arsenic present in fish and mollusks is in the organic form and, as stated by Trumbo et al. [35] as well, these forms are less toxic than inorganic form (for whom the assessment is done). Consequently, any increased health risk from food products such as fish and mollusks is unlikely.

Regarding non-essential trace elements, The European Union legislation (Commission Regulation (EC) 1881/2006 and its amendment (Commission Regulation (EU) 420/2011) on food safety clearly establish the MRLs for total $\mathrm{Cd}, \mathrm{Pb}$ and $\mathrm{Hg}$ which can be detected in the muscle of crustaceans $\left(0.5 \mu \mathrm{g} \mathrm{g}^{-1}\right.$ w.w. for $\mathrm{Cd} ; 0.5 \mu \mathrm{g} \mathrm{g}^{-1}$ w.w. for $\mathrm{Pb}$ and $0.5 \mu \mathrm{g} \mathrm{g}{ }^{-1}$ w.w. for $\mathrm{Hg}$ ) intended for human consumption $[45,46]$. The results obtained in the current study show lower levels of $\mathrm{Cd}, \mathrm{Pb}$ and $\mathrm{Hg}$ in $\mathrm{AbM}$ and Hep from ViL and SeA sites than the MRLs reported by EU regulations. Furthermore, our data are largely below the established MRLs, suggesting a limited $\mathrm{Cd}, \mathrm{Pb}$ and $\mathrm{Hg}$ contamination of the aquatic environment of the study areas, and good food safety of aquatic products derived from these geographic areas.

\section{Conclusions}

The accumulation of trace elements in P. clarkii tissues reflects the concentrations of metals in the surrounding environment [5] and our data suggest that $P$. clarkii could be considered a good bioindicator for metal pollution. The higher $\mathrm{Cu}$ and $\mathrm{Zn}$ concentrations found in P. clarkii tissues, especially for Zn from ViL site, could be related to higher anthropic activity in these areas, as already proved by a paper by Zaccaroni et al. [23]. However, these results must be evaluated with caution because of the small number of samples collected and the lack of legal limits for the detection of some trace elements concentration in crustaceans and other fish products. The higher As concentrations in crayfish Hep, especially from ViL site, must be further clarified in order to identify possible 
sources of contamination in these areas. Further studies are also needed in determining the percentage of organic and inorganic arsenic in crayfish tissues.

Ongoing studies on metals in a greater number of P. clarkii, in other biological and environmental samples and in other geographical areas, will provide more useful information to confirm this species as indicator of environmental contamination.

Author Contributions: Conceptualization, A.A. and L.S.; methodology, A.A. and A.Z.; software, S.V.; validation, A.A., A.Z., S.B. and L.S.; formal analysis, A.A., S.V., M.S. and R.A.; investigation, A.A., M.S., R.A. and A.Z.; resources, L.S.; data curation, A.A., S.B., A.Z.; writing—original draft preparation, A.A., R.A. and A.Z.; writing-review and editing, A.A., M.D., S.B., A.Z. and L.S.; visualization, A.Z. and L.S.; supervision, L.S. and A.Z.; project administration, L.S.; funding acquisition, L.S. All authors have read and agreed to the published version of the manuscript.

Funding: This research received no external funding.

Institutional Review Board Statement: Ethical review and approval were waived for this study, since P. clarkii is considered an invasive species in Italy which should be eradicated. Its collection is thus allowed without any special permission.

Informed Consent Statement: Not applicable.

Data Availability Statement: Detailed data supporting results are available on request at the corresponding author.

Conflicts of Interest: The authors declare no conflict of interest.

\section{References}

1. Klavinš, M.; Briede, A.; Rodinov, V.; Kokorite, I.; Parele, E.; Klavina, I. Heavy metals in rivers of Latvia. Sci. Total Environ. 2000, 262, 175-183. [CrossRef]

2. Russo, R.; Voi, A.L.; De Simone, A.; Serpe, F.P.; Anastasio, A.; Pepe, T.; Cacace, D.; Severino, L. Heavy Metals in Canned Tuna from Italian Markets. J. Food Prot. 2013, 76, 355-359. [CrossRef] [PubMed]

3. Smith, E.; Naidu, R.; Alston, A. Arsenic in the Soil Environment: A Review. Adv. Agron. 1998, 64, 149-195.

4. Colin, N.; Maceda-Veiga, A.; Flor-Arnau, N.; Mora, J.; Fortuño, P.; Vieira, C.; Prat, N.; Cambra, J.; De Sostoa, A. Ecological impact and recovery of a Mediterranean river after receiving the effluent from a textile dyeing industry. Ecotoxicol. Environ. Saf. 2016, 132, 295-303. [CrossRef] [PubMed]

5. Kouba, A.; Buric, M.; Kozak, P. Bioaccumulation and Effects of Heavy Metals in Crayfish: A Review. Water Air Soil Pollut. 2010, 211, 5-16. [CrossRef]

6. Devi, M.; Thomas, D.A.; Barber, J.T.; Fingerman, M. Accumulation and Physiological and Biochemical Effects of Cadmium in a Simple Aquatic Food Chain. Ecotoxicol. Environ. Saf. 1996, 33, 38-43. [CrossRef]

7. Alcorlo, P.; Otero, M.; Crehuet, M.; Baltanás, A.; Montes, C. The use of the red swamp crayfish (Procambarus clarkii, Girard) as indicator of the bioavailability of heavy metals in environmental monitoring in the River Guadiamar (SW, Spain). Sci. Total Environ. 2006, 366, 380-390. [CrossRef] [PubMed]

8. Bianchi, N.; Fortino, S.; Leonzio, C.; Ancora, S. Ecotoxicological study on lead shot from hunting in the Padule di Fucecchio marsh (Tuscany, Italy). Chem. Ecol. 2011, 27, 153-166. [CrossRef]

9. Martín-Díaz, M.L.; Tuberty, S.R.; McKenney, C.L.; Blasco, J.; Sarasquete, C.; Del Valls, T.Á. The use of bioaccumulation, biomarkers and histopathology diseases in shape Procambarus clarkii to establish bioavailability of $\mathrm{Cd}$ and $\mathrm{Zn}$ after a mining spill. Environ. Monit. Assess. 2006, 116, 169-184. [CrossRef]

10. Anderson, M.B.; Reddy, P.; Preslan, J.E.; Fingerman, M.; Bollinger, J.; Jolibois, L.; Maheshwarudu, G.; George, W.J. Metal Accumulation in Crayfish, Procambarus clarkii, Exposed to a Petroleum-Contaminated Bayou in Louisiana. Ecotoxicol. Environ. Saf. 1997, 37, 267-272. [CrossRef]

11. Reynolds, J.; Souty-Grosset, C. Management of Freshwater Biodiversity: Crayfish as Bioindicators; Cambridge University Press: Cambridge, UK, 2011.

12. Caro, T. Conservation by Proxy: Indicator, Umbrella, Keystone, Flagship, and Other Surrogate Species; Island Press: Washington, DC, USA, 2010.

13. Mancinelli, G.; Papadia, P.; Ludovisi, A.; Migoni, D.; Bardelli, R.; Fanizzi, F.P.; Vizzini, S. Beyond the mean: A comparison of traceand macroelement correlation profiles of two lacustrine populations of the crayfish Procambarus clarkii. Sci. Total Environ. 2018, 624, 1455-1466. [CrossRef]

14. Gedik, K.; Kongchum, M.; DeLaune, R.D.; Sonnier, J.J. Distribution of arsenic and other metals in crayfish tissues (Procambarus clarkii) under different production practices. Sci. Total Environ. 2017, 574, 322-331. [CrossRef] 
15. Goretti, E.; Pallottini, M.; Ricciarini, M.; Selvaggi, R.; Cappelletti, D. Heavy metals bioaccumulation in selected tissues of red swamp crayfish: An easy tool for monitoring environmental contamination levels. Sci. Total Environ. 2016, 559, 339-346. [CrossRef] [PubMed]

16. Bellante, A.; Maccarone, V.; Buscaino, G.; Buffa, G.; Filiciotto, F.; Traina, A.; Del Core, M.; Mazzola, S.; Sprovieri, M. Trace element concentrations in red swamp crayfish (Procambarus clarkii) and surface sediments in Lake Preola and Gorghi Tondi natural reserve, SW Sicily. Environ. Monit. Assess. 2015, 187, 1-18. [CrossRef] [PubMed]

17. Suárez-Serrano, A.; Alcaraz, C.; Ibanez, C.; Trobajo, R.; Barata, C. Procambarus clarkii as a bioindicator of heavy metal pollution sources in the lower Ebro River and Delta. Ecotoxicol. Environ. Saf. 2010, 73, 280-286. [CrossRef]

18. Gherardi, F. Crayfish invading Europe: The case study ofProcambarus clarkii. Mar. Freshw. Behav. Physiol. 2006, 39, 175-191. [CrossRef]

19. Gherardi, F.; Holdich, D.M. Crayfish in Europe as Alien Species; CRC Press: Boca Raton, FL, USA, 1999.

20. Delmastro, G. Sull'acclimatazione del gambero della Louisiana Procambarus Clarkii (Girard, 1852) Nelle Acque Dolci Italiane (Crustacea: Decapoda: Cambaridae). Pianura 1992, 4, 5-10.

21. Maselli, V.; Polese, G.; Rippa, D.; Ligrone, R.; Rastogi, R.K.; Fulgione, D. Frogs, sentinels of DNA damage induced by pollution in Naples and the neighbouring Provinces. Ecotoxicol. Environ. Saf. 2010, 73, 1525-1529. [CrossRef] [PubMed]

22. Marfe, G.; Di Stefano, C. The evidence of toxic wastes dumping in Campania, Italy. Crit. Rev. Oncol. 2016, 105, 84-91. [CrossRef]

23. Zaccaroni, A.; Corteggio, A.; Altamura, G.; Silvi, M.; Di Vaia, R.; Formigaro, C.; Borzacchiello, G. Elements levels in dogs from "triangle of death" and different areas of Campania region (Italy). Chemosphere 2014, 108, 62-69. [CrossRef]

24. Ariano, A.; Marrone, R.; Andreini, R.; Smaldone, G.; Velotto, S.; Montagnaro, S.; Anastasio, A.; Severino, L. Metal Concentration in Muscle and Digestive Gland of Common Octopus (Octopus vulgaris) from Two Coastal Site in Southern Tyrrhenian Sea (Italy). Molecules 2019, 24, 2401. [CrossRef] [PubMed]

25. Pereira, P.; Raimundo, J.; Vale, C.; Kadar, E. Metal concentrations in digestive gland and mantle of Sepia officinalis from two coastal lagoons of Portugal. Sci. Total Environ. 2009, 407, 1080-1088. [CrossRef] [PubMed]

26. Elia, A.C.; Dörr, A.J.M.; Mastrangelo, C.; Prearo, M.; Abete, M.C. Glutathione and Antioxidant Enzymes in the Hepatopancreas of Crayfish Procambarus Clarkii (Girard, 1852) of Lake Trasimeno (Italy). Bull. Français Pêche Piscic. 2006, 2006, 1351-1361. [CrossRef]

27. Devesa, V.; Súñer, M.A.; Lai, V.W.-M.; Granchinho, S.C.R.; Martinez, J.M.; Vélez, D.; Cullen, W.R.; Montoro, R. Determination of arsenic species in a freshwater crustaceanProcambarus clarkii. Appl. Organomet. Chem. 2002, 16, 123-132. [CrossRef]

28. Mistri, M.; Munari, C.; Pagnoni, A.; Chenet, T.; Pasti, L.; Cavazzini, A. Accumulation of trace metals in crayfish tissues: Is Procambarus clarkii a vector of pollutants in Po Delta inland waters? Eur. Zool. J. 2020, 87, 46-57. [CrossRef]

29. Tan, Y.; Peng, B.; Wu, Y.; Xiong, L.; Sun, J.; Peng, G.; Bai, X. Human health risk assessment of toxic heavy metal and metalloid intake via consumption of red swamp crayfish (Procambarus clarkii) from rice-crayfish co-culture fields in China. Food Control 2021, 128, 108181. [CrossRef]

30. Kuklina, I.; Kouba, A.; Buric, M.; Horká, I.; Ďuriš, Z.; Kozak, P. Accumulation of Heavy Metals in Crayfish and Fish from Selected Czech Reservoirs. BioMed Res. Int. 2014, 2014, 1-9. [CrossRef]

31. Moss, J.C.; Hardaway, C.J.; Richert, J.C.; Sneddon, J. Determination of cadmium copper, iron, nickel, lead and zinc in crawfish [Procambrus clarkii] by inductively coupled plasma optical emission spectrometry: A study over the 2009 season in Southwest Louisiana. Microchem. J. 2010, 95, 5-10. [CrossRef]

32. Eisler, R. Copper Hazards to Fish, Wildlife, and Invertebrates: A Synoptic Review; US Geological Survey; US Department of the Interior: Washington, DC, USA, 1998.

33. Rainbow, P.S. Trace metal concentrations in aquatic invertebrates: Why and so what? Environ. Pollut. 2002, 120, 497-507. [CrossRef]

34. Bruno, G.; Volpe, M.G.; De Luise, G.; Paolucci, M. Detection of Heavy Metals in Farmed Cherax Destructor. Bull. Français Pêche Piscic. 2006, 2006, 1341-1349. [CrossRef]

35. Trumbo, P.; Yates, A.A.; Schlicker, S.; Poos, M. Dietary reference intakes: Vitamin A, vitamin K, arsenic, boron, chromium, copper, iodine, iron, manganese, molybdenum, nickel, silicon, vanadium, and zinc. J. Am. Dietetic Assoc. 2001, 101, 294-301. [CrossRef]

36. Scientific Committee on Food. Opinion of the Scientific Committee on Food on the Tolerable Upper Intake Level of Copper; Scientific Committee on Food: Brussels, Belgium, 2003.

37. EFSA Panel on Dietetic Products, Nutrition and Allergies (NDA). Scientific opinion on dietary reference values for copper. EFSA J. 2015, 13, 4253. [CrossRef]

38. BfR, Proposed Maximum Levels for the Addition of Copper to Foods Including Food Supplements; German Federal Institute for Risk Assessment: Berlin, Germany, 2021; pp. 1-4.

39. López, F.J.S.; Gil García, M.D.; Vidal, J.L.M.; Aguilera, P.A.; Frenich, A.G. Assessment of metal contamination in Doñana National Park (Spain) using crayfish (Procamburus clarkii). Environ. Monit. Assess. 2004, 93, 17-29. [CrossRef] [PubMed]

40. Scientific Committee on Food. Opinion of the Scientific Committee on Food on the Tolerable UpperIntake Level of Zinc; Scientific Committee on Food: Brussels, Belgium, 2003.

41. Adams, M.A. Guidance Document for Chromium in Shellfish; Center for Food Safety and Applied Nutrition: Chicago, IL, USA, 1993.

42. Schmitt, C.J.; Brumbaugh, W.G.; Linder, G.L.; Hinck, J.E. A Screening-Level Assessment of Lead, Cadmium, and Zinc in Fish and Crayfish from Northeastern Oklahoma, USA. Environ. Geochem. Health 2006, 28, 445-471. [CrossRef] [PubMed] 
43. Scientific Committee on Food. Opinion of the Scientific Committee on Food on the Tolerable UpperIntake Level of Trivalent Chromium; Scientific Committee on Food: Brussels, Belgium, 2003.

44. WHO. Trace Elements in Human Nutrition and Health; WHO: Geneva, Switzerland, 1996.

45. EC European Commission. Commission Regulation (EC) No 1881/2006 of 19 December 2006. Setting maximum levels for certain contaminants in foodstuffs. Off. J. Eur. Union 2006, 364, 324-365.

46. EC European Commission. Commission Regulation (EU) No 2011/420 of 29 April 2011. Amending regulation (EC) No 1881/2006 setting maximum levels for certain contaminants in foodstuffs. Off. J. Eur. Union 2011, L 111, 3-6. 